\title{
The United Nations High Commission for Refugees and its Concern for African Refugees
}

\author{
J.Adele Bamgbose \\ Department of Political Science, Lagos State University Ojo, Lagos State, Nigeria \\ E-mail: bamgboseja@yahoo.com
}

KEYWORDS Colonialism; refugee problem; internally displaced people; human rights

\begin{abstract}
The long standing refugee problem on African continent dates back to the period of decolonization that followed colonialism in Africa when some African nationalists rose up to challenge the Whiteman domination and exploitation of the continent. Africans became refugees and internally displaced people while escaping or fleeing political persecution that characterized the decolonization process. Today, the nature of refugee crisis has changed worldwide. The end of cold war era has aggravated refugee out flows and internally displaced person. As a result of the cold war phenomenon, Africa became a refugee continent as she is harbouring the highest number of refugees in the world. But international responses to protect and assist different categories of dislocated people dated back to 1921 when Fridtjof Nansen was appointed an High Commissioner for Refugees of the League of Nations. Against this backdrop, the purpose of this paper is to offer a general overview of the performance of the United Nations High Commission for Refugees towards alleviating problems confronting African refugees.
\end{abstract}

\section{INTRODUCTION}

The history of mankind shows a variety of movements within the world system. For instance, during the industrial revolution, people moved from the developed countries to less developed countries in order to have access to the raw materials of the colonies; to have markets for the sale of their manufactured goods and as a field for the investment of surplus capital (cited in Nkrumah, 1973: 3). Inter-regional and international movements of people have been claimed to be the result from inequalities in income and wealth (Prothero, 1987: 1283). This purports that, no society is static and that the history of every continent, whether developed or developing, has been marked by significant migratory movements at every stage. With increase in population, man-made and natural disasters ${ }^{1}$ became pronounced and these have been causing greater population movements in the present than in the past. Population movements therefore have become complex as such movements could be found within and among countries of the Third World and between the Third World and countries with more developed economies (Prothero, 1987: 1283).

Associated with such man-made and natural disasters are the phenomena of refugees and the internally displaced people which were once known and confined to Europe but have now become ubiquitous with the Third World Countries having the lion share of both the refugee production and refugee hosting. This fact has been corroborated by many scholars. For instance, Smyser (1985) has pointed out that: "The overwhelming majority of refugees are now from developing countries" (Smyser, 1985: 160). Gil Loescher and Laila Monahan were closed to this claim when they admitted that larger numbers of so-called "Third World' nationals began fleeing politically repressive and desperately poor regimes to seek refuge in Europe and North America" (Loescher and Monahan, 1989: 17).

However, of these Third World Countries, Africa is the most vulnerable with the highest number of refugee repatriates and second largest contributor of the world refugees (Afolayan, 2003: 66). Besides, the UNCHR has once argued that "the economic effects of hosting refugees are mostly felt in Africa" (Phillips, 2003: 1). This very sad and pathetic African refugee situation has been variously described by commentators and the world leaders. Both Nwosu and Djebah have described African refugee situation as been "degenerated from manageable to bad and from there to worse" (Nwosu and Djebah, 1996: 13), while Alhaji Mohammed, the Nigerian Executive Chairman of National Commission for Refugees (NCFR) once said that "it is sad to note that as more African countries attained independence, the refugee population has continued to increase" (Oketunbi, 2000: 19). This worsening African situation has been largely due to the fact that Africa harbours the largest number of most economically backward regions and the 
largest number of least developed countries in the world (Adepoju, 1982: 29). The implication of this situation for Africa is that, most of these African countries that harbour these refugees are economically poor and they cannot improve refugee conditions in any way. Tanzania demonstrated such poor state against the Rwandese and Burundi refugees by forcefully returned these refugees back to their countries (UNHCR Information Bulletin, 1995: 2). Since the influx of 3,000 Liberian refugees to Nigeria between June and July 2003 the capacity of the camp at Oru-Ijebu (Ogun State) had been stretched beyond its limit thereby creating an acute problem of shelter (Odiaka, 2005: 15). Similarly, for more than three weeks, a Russian ship, Zolotista, with about 400 refugees from wartorn Liberia was adrift on the West Coast as none of the coastal states seemed needy to let it berth (Nwosu and Djebah, 1996: 13)

African refugee situation did not start overnight, it has been a gradual process as Hamrell also admitted that "... refugee problem has emerged gradually all over the African continent" (Hamrell, 1967: 9) and in the words of Christensen, refugee phenomenon has been part of the history of African countries before independence ${ }^{2}$ (Christensen, 1985: 23). However, September 1961 marked the genesis of massive movement of refugees in Africa (Adepoju, 1982: 30) because the period coincided with the rise of national independence movements and the attainment of independence. As at 1961, African refugee population stood at 100,000 ; by 1964 , this stood at 400,000 refugees, by 1967 , there were more than 750,000 refugees in Africa. Thus the 1967 figure increased rapidly to 1 million in 1980 and 5 million in 1981 (Adepoju, 1982: 30), and by 2005 , African refugees stood at 7 million (Odiaka, 2005: 15).

Paradoxically, the end of Cold World War which people had thought would bring peace and stability in the world failed to bring these expectations, instead, increasing waves of violence rooted in conflict became the dominant issue world wide which resultantly led to the production of refugees out flows which badly affected and worsened refugee situation in Africa. Almost all African countries are affected because as it is now, when any African country does not experience refugee outflows, it must experience internal displacement and when it does not experience any of these, such a country must host refugees from neighbouring countries. Presently, Africa's largest refugee populations came from Burundi with 570, 000, Sudan with 490, 000, Angola 421,000, Democratic Republic of Congo with 395,000 and Somalia with 357,000 (UNHCR Refugees, 2003: 15) while African countries hosting the largest refugee populations include Tanzania with 690,000, Democratic Republic of Congo with 330,000, Sudan 328,000, Zambia 247,000, Kenya 234, 000 and Uganda with 217,000 refugees. But the sorry state which African countries find themselves is that with poor economy and abject poverty, some of these countries both experience and host refugees in large numbers.

African countries are not only prone to refugees but as well as internally displaced people ${ }^{3}$. The latter differs from the former because the internally displaced persons have not crossed the international boundary of another nation. Thus while attention has long been focused on the plight of the refugees, internally displaced persons is only recently receiving attention (Ibeanu, 1998: 84). Where attention has been focused on the refugees, a number of inhuman treatments such as rape, forced sexual intercourse or other sexual acts with family members, forced impregnation, forced pregnancy, sexual mutilation, sexual humiliation, medical experimentation on women's, sexual abortion, forced sterilization, forced prostitution, being compelled to exchange sexual favours for essential items or services, being compelled to exchange sexual favours or the return of children, trafficking in women, pornography and forced cohabitation/marriages (Gardam and Jarvis, 2000: 12 and 13) are rampant among the women refugees.

Demographically, women constitute a large percentage of the world refugees and displaced people. Refugee Policy Group report (1992) stated that about 15 million people were internally displaced in Africa and that a larger proportion of these people were women and children (Refugee Policy Group Report, 1992: 1). One important factor accounting for fewer men is that, during crisis, some of these men are forcefully conscripted while most of these men lost their lives during the crisis.

Other areas are not left out. Thus, the Afghanistan refugee crisis started with the Soviet invasion which had led to displacement of many people. By the end of 1980, nearly two million 
refugees fled to Pakistan and Iran (Petrin, 2002:13; Van Hear, 2003:5). This number increased to six million later following the outbreak of war between the Muslim resistance or mujahedin and the Soviet-backed Kabul regime. Many of these six million refugees returned to Afghanistan following a temporal stoppage of the conflict. The outbreak of the conflict again made several of them to leave Afghanistan for Pakistan and Iran. While it is true that most Afghan refugees are found in Pakistan and Iran, other areas where they could be found include India and Russia.

The conflicts of 1948, 1967 and the subsequent ones have no doubt led to a wide dispersal of Palestinians. Most of these Palestinians refugees are found in West Bank and Gaza; in Jordan, Lebanon, Syria and Egypt; in Kuwait, Gulf States and North Africa; in Europe, North America among others. Since the civil war between the Sri-Lankan armed forces and the Liberation Tigers of Tamil Eelam (LTTE) took off in the 1983, a large scale outflow of asylum-seekers have been reported, mainly the Tamil. Thus, by 1990s, there were some 100,000 Sri-Lankan refugees in Southern India, and 200-300,000 in Europe and North America.

\section{ORIGIN OF UNHCR}

Refugees of all demographic compositions male, female and children are human beings like other free born citizens who can still become useful in their countries of origin or elsewhere in the world. However, while it is undeniable that the international community assisted these refugees, they initially faced sheer neglect ${ }^{4}$. Thus with the outbreak of the World War I, refugee situation took a new problematic dimension because of the magnitude of refugee outflows and internally displaced persons. By the end of 1915 refugee population stood at 2.7 million while internally displaced persons were 5 million. Even though, the First World War ended in 1918, ripples caused by the war continued to generate more refugees as this reached 9.5 million in 1926 (Zolberg et al., 1989: 18). It was against this background that the League of Nations created the office of the High Commissioner for Refugees to take care of these refugees, and subsequently, Fridtjof Nansen became the first High Commissioner of this body.

With the Second World War, what Nansen thought would be a temporary task under the
League of Nations that is, assistance to the refugees continued as a result of political instability in Europe which triggered a new refugee problem. This culminated into the formation of the United Nations Relief and Rehabilitation Administration (UNRRA) on November 9, 1943. The UNRRA was followed by the creation of International Refugee Organisation (IRO) in 1946 and by 1947, a Preparatory Commission for IRO was established and on July 1st 1947, the Commission took over the functions and activities previously exercised by UNRRA such as responsibility for emergency relief and repatriation, maintenance and rehabilitation. The International Refugee Organisation (IRO) succeeded the Preparatory Commission on August 20, 1948 and by the time it ceased operation in February 1952, it (IRO), had resettled more than a million displaced persons and refugees throughout the world, repatriated approximately 73,000 and had altogether given assistance to more than, $1,600,000$ persons (United Nations Publication, 1968:341).

An upsurge of refugees mainly the Palestinian refugees following the creation of the state of Israel led to the establishment of the United Nations High Relief and Works Agency for Palestine Refugees in 1949. However, when IRO was dissolved, the United Nations appointed a United Nations High Commissioner for Refugees in 1949. By December 14, 1950, the General Assembly adopted the Statue of the office of the United Nations High Commissioner for Refugees. The office came into existence on January 1,1951 . The office was initially created for three years but the persistent refugee crisis has made the body a permanent one. Since 1951 that the office had come into existence, nine High Commissioners have served in the office. These are Mr. Gerrit J. Van Heuven Goedhart, Mr. Auguste R. Lindt, Mr Felix Schnyde, Mr Sadruddin Aga Khan, Mr. Poul Harting, Mr. JeanPierre Hocke, Mr. Thorvald Stoltenberg, Mrs. Sadako Ogata and Mr. Rudd Lubbers.

The Commissioner is appointed by the General Assembly on the nomination of the Secretary General. The High Commissioner's programme is administered by a thirty-member Executive Committee which generally meets twice a year at Geneva. The UNHCR'S Executive Committee is made up of governments which have a particular interest in refugee matters, many 
of which are important asylum countries or major donors to the UNHCR programmes (UNHCR Refugees, 2000: 170)

\section{UNHCR'S CONCERNS FOR AFRICAN REFUGEES}

Though, the United Nations High Commission for Refugees was not the first body to be associated with refugees as there had been other bodies before it; yet, the functions either associated with the former or the latter bodies have not changed. Its work is humanitarian, social and non-political. Its basic tasks are to provide international protection for refugees within the High Commissioner's mandate and to seek permanent solutions to their problems by facilitating their voluntary repatriation or their assimilation.

In order to promote and safeguard the rights of refugees, the UNHCR tries particularly:

1. To encourage governments to subscribe to international and regional conventions and arrangements concerning refugees, returnees and displaced people, and to ensure that the standards they set out are effectively put into practice.

2. To promote the granting of asylum to refugees that is, to ensure that they are admitted to safety and protected against forcible return to a country where they have reason to fear persecution or other serious harm,

3. To ensure that applications for asylum are examined fairly and that asylum seekers are protected, while their requests are being examined against forcible return to a country where their freedom or lives would be endangered,

4. To ensure that refugees are treated in accordance with recognized international standards and receive an appropriate legal status including, wherever possible, the same economic and social rights as nationals of the country in which they have been given asylum,

5. To help refugees to cease being refugees either through voluntary repatriation to their countries of origin, or, if this is not feasible, through the eventual acquisition of the nationality of their country of residence,

6. To help reintegrate refugees returning to their home country in close consultation with the government concerned and to monitor amnesties, guarantees or assurances on the basis of which they have returned home,

7. To promote the physical security of refugees, asylum - seekers and returnees, particularly their safety from military attacks and other acts of violence,

8. To promote the reunification of refugee families (UNHCR Refugees, 2000: 171 and 172). It is on the basis of substantially improving the above functions that the United Nations High Commission for Refugees concluded in 2003 that it would ensure:

a. Staff security and recognition of the need to preserve "humanitarian space";

b. On going support to resolve protracted situation;

c. Willingness to commit and provide concrete support in order to ensure the sustainability of refugee repatriation movements through post- conflict reconstruction processes and longer-term measures;

d. Responsibility and burden sharing with host countries;

e. Preservation of principles and practice of international protection for refugees through further clarification of global migration asylum issues (UNHCR Report, 2003: 17)

Though the United Nations High Commission for refugees (UNHCR) is associated with the plight of the refugees, its efforts on refugees was initially restricted. The body had nothing to do with the African refugees but rather European refugees.

But with the era of decolonization which gathered momentum after the Second World War, Africans came into confrontations with the Europeans settlers resulting into the fleeing of the former (Africans) to the neighbouring countries. Virtually no assistance came to these African refugees when Africa started to experience refugee crisis. Thus by May 1957, there were already about 50, 000 Algerian refugees in Tunisia (Ajala 1998: 135). The figure increased tremendously later. The upsurge attracted the attention of the then Tunisian Prime Minister Habib Bourguiba who asked the UNHCR to examine the way in which the High Commissioner would be able to help his government to resolve the problem of Algerian refugees. The agency responded and five years later helped to repatriate $260,000^{5}$ Algerian refugees from Tunisia and Morocco. This became the first time that the 
UNHCR would be involved in such assistance in Africa and by 1962, the UNHCR opened its first office in sub-Saharan Africa in Burundi.

The Algerian episode was closely followed by the Ethiopian refugees in Sudan in 1967. These were made up of Eritrean who crossed the borders to escape clashes between the Eritrean freedom fighters and the Ethiopian Army. As the influx of these refugees continued in Sudan, the Sudanese government sought the help of the UNHCR. The UNHCR therefore responded by making the sum of $\$ 150,000$ available for the purchase of food and medical equipments. This was followed by a release of $\$ 1$ million by the UNHCR for the construction of reservoirs and pipelines to bring water to the villages where the refugees were to reside.

In 1975 when the nationalist struggle began in Zimbabwe, an initial stream of 15,000 refugees entered Mozambique. The figure increased later to 150,000 refugees by the end of 1979 (Adepoju, 1982: 29). By 1981, 600,000 Zimbabwean returning refugees benefited from the humanitarian programme of the UNHCR; aside, the UNHCR helped in the integration of these refugees which was handled through the provision of seed, fertilizers, farming implements and vehicles as well as food and shelter.

In 1977 when war began in the Horn of Africa, as many as three million Somalis and Ethiopians were displaced and a year later, UNHCR launched an assistance programme for the Ethiopian refugees in the neighbouring countries. With the support of the Ethiopian government, a project was established to help receive and rehabilitate refugees returning to Ethiopia. Such help centred around the construction and equipment of reception centres and the provision of material needs. The body also resettled 3, 030 Ethiopians by 2003 (UNHCR Report, 2003: 8).

The Somalian refugee phenomenon became worsened following massive Ethiopian refugee influx. The number of refugees in Somalia rose from 70,000 in July to 380,000 in September 1979. By December 1979, the 470,000 refugees had increased to 600,000 by February 1980 . This got increased later to 700,000 in May, 1980. The UNHCR intervened by launching an appeal fund of US \$ $40.7 \mathrm{~m}$ for assistance other than food to the refugees. Aside, the UNHCR concentrated assistance on immediate relief such as clothing, shelter, medicine and so on. The body also helped in resettlement of 12,000 Somali Bantu refugees who had waited for a decade in Kenya camps. (UNHCR Report, 2002: 9). By 1997, the body began voluntary repatriation of Somali refugees and by the end of 1999, the body had assisted 88, 230 out of 129, 160 repatriates (Afolayan, 2003: 77). Equally by 2003 a total number of 10,300 Somalian refugees were repatriated (UNHCR Refugees, 2003: 7).

The impact of United Nations High Commission for refugees was greatly felt in Uganda. Thus after the overthrow of the Amin regime, the UNHCR launched a $\$ 7$ million Special Programme of Humanitarian Assistance in Uganda. Responsibility for the Programme was transferred to a special Representative of the UN Secretary General in March 1981. Such effort was complemented in June 1981 when president Obote of Uganda participated in a summit meeting with President Numeiri of Sudan and President Mobutu of Zaire which helped to encourage voluntary repatriation of Ugandan refugees. Aside, the UNHCR allocated the sum of $\$ 700,000$ to the Ministry of Rehabilitation for the reception and reintegration of refugees returning to West Nile. Between 1981 and 1984, the UNHCR raised an additional $\$ 2.5$ million for Ugandan returnees, and in May 1984, a special appeal for a further $\$ 5$, million was launched (Crisp, 1986: 166). Such assistance continued when the UNHCR in 1988 repatriated 8,000 Uganda refugees from Sudan.

Kenya experienced the influx of refugees from different countries (Wilkin, 1980: 510) (Adepoju, 1982: 28) such as Uganda, Ethiopia, Rwanda and Mozambique. The problem of Kenyan refugees was less acute at first because the country's official refugee population was less than 15,000 (Crisp, 1999: 17). These people who were composed mainly of Ugandans found employment in Kenya. The situation changed suddenly in the early 1990s following armed conflicts and human rights violations in the neighbouring states of Ethiopia, Somalia and Sudan which prompted massive population displacements to Kenya. By 1992, the number of these refugees stood at 420,000 and was 178,400 by 1996 .

Most of the camp settlements in Kenya were riddled with insecurity problems such as sexual abuse against the women and girls, armed robbery especially at Dadaab camp, violence within national refugee groups especially at the Kakuma camp and violence between refugees and local populations. But in spite of these 
problems, the United Nations High Commission for Refugees (UNHCR) set up machineries to remove these problems. The body set up police force and to enable the police function effectively, vehicles, spare parts, fuel, and radio network were provided. In addition, the organisation supplemented the wages of police based in the camps and also paid bonuses for escort and food distribution duties. The UNHCR also created Community organisation which was designed to empower the refugees and to boost their involvement in camp life in Kakuma and Dadaab camps. The UNHCR with the German Agency fenced the camps round to prevent intruders entering the camps at night. Other facilities provided included provision of firewood needs thereby limiting the need for women and girls to venture to the bush. Education and recreational facilities were as well provided.

Malawi, a drought stricken country with a population of 8 million presents another harrowing experience within the continent. It produces and hosts thousands of refugees from the neighbouring countries. The country received the highest number of refugees in the 1990s. In 1992 for instance, the number of refugees received by Malawi stood at 1,058 refugees (Afolayan, 2003: 74). By 2005 about 1.6 million were facing risk in Malawi (Odiaka 2005: 15). In all these instances, the UNHCR proved itself through its financial contributions towards the plight of Malawian refugees. Such financial contributions stood at \$4.5 million in 1987, \$22.9 million in 1988, \$19.6 million in 1989, \$23 million in 1990 and \$28 million in 1992 (Philips, 2003: 10).

Nigeria, though, not a major refugee producer but is being fed with refugees from neighbouring countries such as Chad, Liberia, and Sierra Leone. The UNHCR began operation in Nigeria in 1978/79 when a counselling office was established under the aegis of the United Nations Development Programme (UNDP) office in Nigeria and this was being supervised by the UNHCR Regional Office in Dakar, Senegal. The UNHCR's functions as at then were very light which included provision of sponsorship and placement of students from liberation organisations like ANC, SWAPO and ZAPU into secondary and higher institutions and giving of financial allowances to a small number of jobless refugees (Ogunkanmi, 1996: 7). However, in 1982, the UNHCR opened a full fledged office in Nigeria and was upgraded to meet up with ever burgeoning refugee responsibilities such as protection of refugee, interaction with government on their behalf, provision of necessary assistance ${ }^{6}$.

The impact of the UNHCR was also felt in Angola because, the body embarked on repatriation of Angolan refugees from Zambia which started in 1995. (Bakewell, 1999: 14). The programme aimed at providing transport for refugees from their official settlements back to Angola. The UNHCR ensured settlement assistance including such elements as food aid, kitchen sets, seeds and tools. Immigration formalities and road construction from Zambian border to Angolan town of Cazombo, the capital of the district from which most Angolans in Meheba district of Zambia originated. By 1997, quick impact projects (QIPS) were undertaken around Cazombo, eight schools were repaired and the district hospital was reopened with 50 beds. Even though little was achieved on the UNHCR repatriation programme, it made its impact known as its assistance to refugees was concerned in the region.

Rwanda is another case of reference. The Rwandan conflict which resulted into the influx of Rwandan refugees to the neighbouring countries had both immediate and remote causes (Adisa, 1996: 11). By April 1994, refugees begun to arrive in large numbers at the Kagera region of North West Tanzania and when the problem persisted, Rwandan refugees were found in all the Tanzanian camps. On December 5, 1996, the Tanzanian government and the UNHCR issued a joint statement and stated Inter alia that : "all Rwandese refugees in Tanzania are expected to return home by 31 December 1996" (Cited in Whitaker, 2002: 1). In preparation for this, the UNHCR distributed informal sheets to refugees about the repatriation exercise. Even though the Rwandese refugees were not willing to go back to Rwanda following this preparation by the UNHCR which resulted into these refugees fleeing in all directions to escape repatriation to Rwanda, the UNHCR sought to calm the situation by holding regular food distributions in the camps which brought some refugees back from the woods and those who did not return were rounded up a week later when UNHCR sent trucks to bring them back to the camps.

However, during the repatriation exercise, the UNHCR provided both financial and logistical assistance to the Tanzanian government. It gave the Ministry of Home Affairs more than \$1.5 
million. Trucks were provided by the UNHCR to transport vulnerable groups such as pregnant women, children and elderly people. In the Rwandan border town of Gisenyi, UNHCR provided full assistance to more than 10,000 people from Masisi encamped at Petite Barriere immigration compound at Nkamira transit centre, while the body (UNHCR) responded to the government request by providing food, water, sanitation and health facilities to the returnees.

The activities of UNHCR were also felt within the West African sub-region when the areas began to be plagued by the refugee crises. In Sierra Leone, the UNHCR had assisted more than 220,000 Sierra-Leonian refugees and hundreds of thousands of internally displaced persons to return home in 2001 and 2002 including around 26,000 refugees in 2003. The UNHCR coordinator of the programme Mr. Jef Groby pointed out that the refugees upon arrival at the Lungi International Airport in Sierra Leone would be received by UNHCR staff and be briefed on the situation in their area of origin and offered available assistance. The UNHCR opened five new offices in returnee areas and appealed to international donors for a nine-fold increase in its budget for Sierra Leone to $\$ 18$ million to carry out community -based reintegration programme such as construction of schools, health clinics and road repairs (USCR, 2002: 4). In addition, the UNHCR embarked on the construction of a new camp with 10,000 person capacity in eastern Sierra Leone's Kenema District to accommodate the refugee influx.

The UNHCR repatriated between 350,000 to 400,000 Liberian refugees since 1997 including at least 40,000 returnees during 2000 while only 2,000 refugees returned home during 2001. The UNHCR had to suspend its formal repatriation programme and ceased most reintegration projects in late 2000 and throughout 2001 as the country's instability worsened.

When some 70,000 Liberian refugees living in western Cote d' Ivoire suffered attacks by Ivorians who viewed the refugee population as a security threat ${ }^{7}$, about 30, 000 frightened Liberian refugees fled Cote d' Ivoire to Liberia despite the danger that awaited them in Liberia. It was the UNHCR officials in Cote d' Ivoire who evacuated the remaining Liberian refugees to safer countries such as Ghana and Benin.

Guinea over the time became a primary asylum country for West African refugees. Refugee influxes during the 1990s were so over whelming. In fact, Drumtra claimed that Guinea hosted the largest refugee population in the continent (Drumtra, 2003: 6). Some 120,000 Liberians and up to 50,000 Sierra Leonean refugees resided in Guinea as of July 2003. The UNHCR was much concerned with the state of the refugees when Mr. Lubbers, the United Nations High Commissioner for Refugees arrived in Guinea to assess the plight of hundreds of thousands of refugees who were trapped in Guinea. Lubbers met with authorities in the Guinean capital to appeal for improved regional security to protect the refugees as well as internally displaced Guineans.

With an end of hostilities in Mali, UNHCR was able to begin important repatriation operation in 1995 and its complete returns in 1997 from neighbouring Mauritania and Burkina Faso.

In 1993, after some very difficult negotiation, the Eritrean authorities and the United Nations agreed upon a $\$ 260$ million repatriation and reintegration programme for refugees in Sudan and in November 1994, UNHCR launched a six month pilot project involving the return of 25,000 Eritrean refugees (Crisp, 2002: 4). Thus between June and September 1989 the UNHCR repatriated almost 434,000 Namibians (Gopalkrishna, 2005: 37)

The refugee crisis became worsened in the former Zaire renamed Democratic Republic of Congo as a result of the outbreak of conflict as Laurent Kabila's rebels began their move to oust Mobutu Sese Seko. These refugees fled mostly to Burundi and some to Angola and Zambia while majority of them fled to Tanzania, Zambia and Rwanda. The UNHCR had been so magnanimous in all these instances to set up camps to these fleeing refugees. Besides, it signed agreements with various governments to ensure the repatriation of those refugees wanting to go back to Democratic Republic of Congo.

The outbreak of the Sudanese civil war in the region of Darfur since February 2003 had caused much devastation to humanity. Thus between February 2003 when the crisis broke out and October, an estimate of 70,000 deaths were recorded. The United Nations put the figure in January 2004 at 3,000 deaths, 10,000 in March 2004 and 70,000 in October 2004. Since three years that the war had started, about 300,000 had lost their lives and 2.5 million had been displaced. Several refugees had fled to Republics of Chad, Egypt, Ethiopia, Kenya, Central African Republic 
and Democratic Republic of Congo. However, with this chronic refugee situation more than 20,000 refugees had been relocated in different camps and nearly 90,000 remained in adhoc settlements.

A declaration of the Principles for the Resolution of the Sudanese Conflict which was signed at Abuja in Nigeria by the Sudanese government, the Sudan Liberation Movement and the smaller Justice and Equality Movement (Rutte, 2005 : 34) brought about the return of a number of Internally Displaced Persons (IDPS) to their villages which was facilitated by the United Nations High Commission for Refugees (UNHCR). The body had offered humanitarian assistance to the returnees.

There are other numerous places in Africa as tables 1 and 2 show where the impact of the United Nations High Commission for refugees (UNHCR) has been greatly felt in Africa. In fact, UNHCR Refugees (2003) rightly put it when it stated that: "There are an estimated 15 million refugees, internally displaced and other uprooted persons throughout the African continent and that UNHCR cared for nearly 4.6 million of them..." (UNHCR Refugees, 2003: 15).

In spite of all these, the activities of UNHCR could be seen in other areas. The body has concerned itself with the repatriation programmes in Afghanistan with over two million refugees, who have returned from Pakistan. The UNHCR's operation in Pakistan has gained increased profile since the American military action in Afghanistan. This has invariably increased the budget from $\$ 16,499,652$ in 1999 and $\$ 17,913,028$ in 2000 to $\$ 35,203,309$ in 2001 (Phillips, 2003:13). More than 100,000 Chechnya civilians have been assisted by the UNHCR during the Russian offensive against the separatist Russian Republic of Chechnya. An estimated 250,000 people fled the Russian offensive against the separatists in 1999 (Helping Refugees, 2003:12). The conflict in Sri-Lanka, which has been raging since 1980s has displaced a large number of people which the UNHCR has continued to maintain a full time protection presence (Report of a Joint Appraisal Mission, 2002: 3). As the UNHCR has concerned itself with the plight of internally displaced persons in Sri-Lanka, so also has it demonstrated this in Bosnia. The body has distributed large quantities of UNHCR food to the affected Muslims and Croats in Bosnia.
However, in spite of the fact that since the creation of the UNHCR in 1950, it is having a special role to play in trying to protect refugees, there has been a sharp contrast in this special role. Much attention has been focused in the treatment of European refugees than African refugees. Often time, it has become very difficult to get fund to take care of African refugees from the UNHCR in such a way that the European refugees have been taken care of.

\section{PROBLEMS AND PROSPECTS}

No one could deny the impact of the United Nations High Commission for Refugees (UNHCR) in the world and in particular in Africa. It was in 1951 that the body was created in response to refugee flows caused by World War II. It was generally concerned with protecting individual refugees from the new communist regimes in Eastern Europe ( Whitaker 2002, 4). But by the 1960s interest shifted to the developing nations as a result of liberation war that characterised most of these countries especially African countries which triggered off refugee crisis. It was through this that the impact of the UNHCR started to be felt in Africa.

However, in spite of different activities by the UNHCR, it is still being confronted by a number of problems. One of such problems is the lack of donor response to appeals for funds which has been forcing UNHCR to scale down its programmes. This had greatly affected the Burundi and Rwandese refugees in the time past. Many of these refugees in Nigeria have equally faced the same problem. For instance, the budget for 1995 was set at $\$ 291.8$ million; as at June 6, 1995 , available funds was $\$ 92.3$ million.

Vicious circle of recurrent conflict and upheaval has been hampering the work of UNHCR and has made nonsense of the repatriation exercise of the UNHCR. The UNHCR had to suspend its formal repatriation programme and ceased most reintegration projects in late 2000 and throughout 2001 as Liberia's instability worsened. The agency (UNHCR) had to close three field offices in March 2001 and was unable to work in one of the country's most important returnee areas. Similarly, in Burundi, continued insecurity hampered UNHCR's repatriation exercise which commenced in 2002.

The changing nature of refugee protection in Africa has been posing enormous problem for 
Table 1: UNHCR expenditure in 2002. Activity by regional bureau/country and types of assistance activity

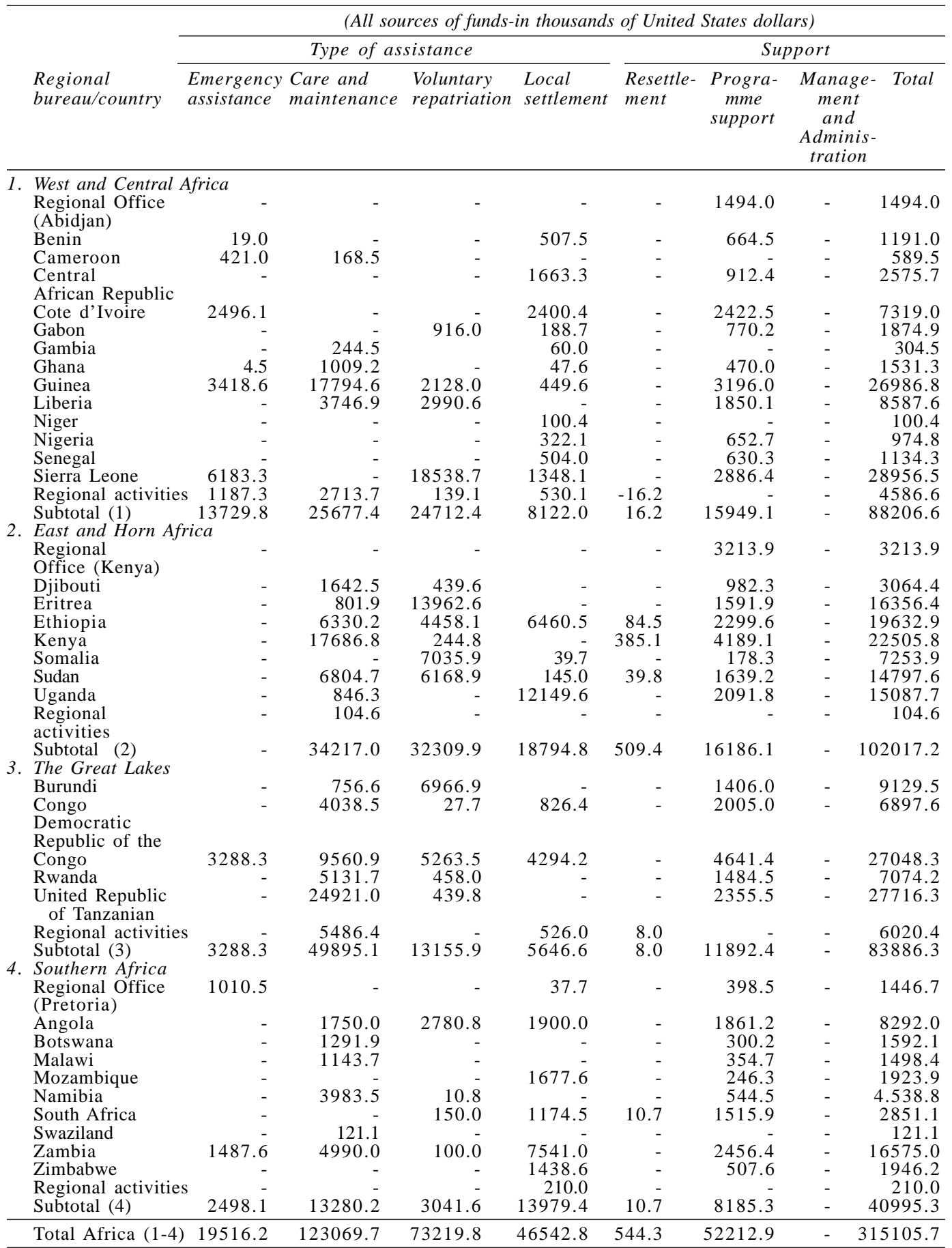

Source: Report of the United Nations High Commissioner for Refugees 2002 Pp. 18 and 19 
Table 2: Asylum-seekers, refugees and others of concern to UNHCR, 2003 figures are provisional and subject to change.

\begin{tabular}{|c|c|c|c|c|c|c|c|c|}
\hline \multirow[b]{2}{*}{ Country ${ }^{l}$} & \multirow[b]{2}{*}{ Refugees $^{2}$} & \multirow[b]{2}{*}{$\begin{array}{l}\text { Of which } \\
\text { assisted } \\
\text { by } \\
\text { UNHCR }\end{array}$} & \multicolumn{6}{|c|}{ Others of concern } \\
\hline & & & $\begin{array}{l}\text { Asylum- } \\
\text { seekers }{ }^{3}\end{array}$ & $\begin{array}{l}\text { Returned } \\
\text { refugees }\end{array}$ & $\begin{array}{l}\text { IDPS of } \\
\text { concern } \\
\text { to } \\
U N H C R^{5}\end{array}$ & $\begin{array}{l}\text { Returned } \\
\text { IDP }\end{array}$ & Various $^{7}$ & $\begin{array}{l}\text { Total } \\
\text { population } \\
\text { of concern }\end{array}$ \\
\hline Burundi & 40,971 & 13,231 & 10,572 & 82,409 & 1,970 & - & - & 135,922 \\
\hline Central African Rep. & 44,753 & 39,314 & 3,419 & 4,857 & - & - & - & 53,0229 \\
\hline Chad & 146,400 & 90,128 & 165 & 598 & - & - & - & 147,163 \\
\hline Congo & 91,362 & 81,946 & 3,224 & 1,780 & - & - & - & 96,366 \\
\hline Dem, Rep of the Congo & 234,033 & 56,105 & 446 & 3,169 & - & - & - & 237,648 \\
\hline Equatorial Guinea & - & - & - & 2 & - & - & - & 2 \\
\hline Gabon & 14,005 & 14,005 & 5,118 & - & - & - & - & 19,123 \\
\hline Rwanda & 36,608 & 36,026 & 23,290 & - & - & - & - & 62,924 \\
\hline Sao Tome and Principe & - & - & - & - & - & - & - & - \\
\hline United Rep. of Tanzania & 649,770 & 479,770 & 163 & 7 & - & - & - & 649,940 \\
\hline $\begin{array}{l}\text { Central African and } \\
\text { the Great Lakes }\end{array}$ & $1,257,902$ & 811,107 & 26,133 & 116,112 & 1,970 & - & - & $1,402,117$ \\
\hline Djibouti & 27,034 & 26,658 & 1,660 & - & - & - & - & 28,694 \\
\hline Eritrea & 3,889 & 3,889 & 200 & 10,148 & - & - & - & 14,237 \\
\hline Ethiopia & 130,274 & 130,274 & 10 & 30 & - & - & - & 130,314 \\
\hline Kenya & 237,512 & 237,512 & 4,023 & 106 & - & - & - & 241,641 \\
\hline Somalia & 368 & 368 & 196 & 10,261 & - & - & - & 10,825 \\
\hline Sudan & 138,163 & 73,717 & 484 & 123 & - & - & 22,024 & 160,794 \\
\hline Uganda & 230,903 & 210,763 & 726 & 4,412 & - & - & - & 236,041 \\
\hline East and Horn of Africa & 768,143 & 683,181 & 7,299 & 25,080 & - & - & 22,024 & 822,546 \\
\hline Angola & 13,382 & 13,363 & 1,006 & 132,977 & - & - & - & 147,365 \\
\hline Botswana & 2,838 & 2,792 & 1,079 & - & - & - & - & 3,917 \\
\hline Comoros & - & - & - & - & - & - & - & - \\
\hline Lesotho & - & - & - & - & - & - & - & - \\
\hline Madagascar & - & - & - & - & - & - & - & - \\
\hline Malawi & 3,202 & 3,202 & 8,848 & - & - & - & - & 12,050 \\
\hline Mozambique & 311 & 311 & 9,225 & - & - & - & - & 9,536 \\
\hline Mauritius & - & - & - & - & - & - & - & - \\
\hline Namibia & 19,800 & 13,800 & 1,992 & 3 & - & - & - & 21,795 \\
\hline South Africa & 26,558 & 5,963 & 84,085 & - & - & - & - & 110,643 \\
\hline Swaziland & 686 & 615 & 327 & - & - & - & - & 1,013 \\
\hline Zambia & 226,697 & 134,370 & 180 & 5 & - & - & - & 226,882 \\
\hline Zimbabwe & 12,721 & 12,721 & 556 & - & - & - & - & 13,277 \\
\hline Southern Africa & 306,195 & 187,1371 & 107,298 & 132,985 & - & - & - & 546,478 \\
\hline Benin & 5,034 & - & 814 & - & - & - & - & 5,848 \\
\hline Burkina Faso & 466 & - & 499 & - & - & - & - & 965 \\
\hline Cameroon & 58,583 & - & 5,675 & 4 & - & - & - & 64,262 \\
\hline Gambia & 7,465 & 1,661 & 1 & - & - & - & - & 7,466 \\
\hline Ghana & 43,947 & 43,947 & 4,087 & - & - & - & - & 48,034 \\
\hline Guinea-Bissau & 7,551 & 7,529 & 79 & - & - & - & - & 7,630 \\
\hline Guinea & 184,341 & 111,491 & 2,544 & - & - & - & - & 186,885 \\
\hline Cote d'ivoire & 75,971 & 75,971 & 1,321 & 16,600 & 38,039 & - & - & 131,931 \\
\hline Liberia & 33,997 & 14,329 & - & 21,000 & 531,616 & - & 15,000 & 601,613 \\
\hline Mali & 10,009 & 10,009 & 715 & - & - & - & - & 10,724 \\
\hline Niger & 328 & - & 34 & - & - & - & - & 362 \\
\hline Nigeria & 9,171 & 6,171 & 1,125 & 7 & - & - & - & 10,303 \\
\hline Senegal & 20,726 & 20,726 & 2,265 & 7 & - & - & - & 22,998 \\
\hline Sierra Leone & 61,194 & 61,194 & 141 & 33,255 & - & - & - & 94,590 \\
\hline Togo & 12,395 & 737 & 333 & 9 & - & - & - & 12,737 \\
\hline West Africa & 531,178 & 35,765 & 19,633 & 70,882 & 569,655 & - & 15,000 & $1,206,348$ \\
\hline
\end{tabular}

Source: Report of the United Nations High Commissioner for Refugees 2003 p.22 
UNHCR because, most of the African countries that had been generous to admit refugees from other countries in Africa are now faced with chronic economic problem making them to either close their borders or force these refugees out of their countries. For instance, Tanzania had once forced the Rwandese refugees out and closed her border to both Burundi and Rwandese refugees and persuasion by the UNHCR to Tanzania to re-open her border had failed to yield a positive result. This has been hampering the humanitarian assistance of the UNHCR. The UNHCR is therefore confronted with dilemmas in which it was obliged to choose between a limited number of options, none of which is fully consistent with the principles which the organisation is mandated to uphold.

The staff of the UNHCR have continued to face serious levels of insecurity to their lives which has resulted in many losing their lives. For examples, in November 2003, Bettina Goislard, a young protection officer working in Ghazni was shot; and in 2004, the brutal murder of five Medecins Sans Frontieres staff in northwestern Afghanistan took place.

Most of the officers for humanitarian purpose are ill equipped to promote self reliance in refugee populated areas. This has been largely due to lack of funds available to the UNHCR for instance, the Liberian refugees at Oru Camp in Nigeria often complain of sheer neglect by the UNHCR making a number of them wanting to go home.

The myraids of problems confronting the UNHCR notwithstanding, the agency has made its impact felt in all regions of the world.

Though when the agency was created in 1951 following the refugee crises in Europe, it exclusively confined its activities to that region alone. The outbreak of refugee crises in other parts of the world especially in the Third World countries took the agency to various refugee infested areas of the world. The agency has joined hand with other Non-governmental organisations to improve the plight of refugees all over the world particularly in African countries.

The UNHCR has greatly increased its assistance to include:

a. help during major emergencies involving the movement of large numbers of refugees,

b. regular programmes in such fields as education, health and shelter,

c. assistance to promote the self-sufficiency of refugees and their integration in host countries,

d. voluntary repatriation,

e. resettlement in third countries for refugees who cannot return to their homes and who face protection problems in the country where they first sought asylum.

There is no doubt that the UNHCR will substantially improve its condition of refugee assistance in the future if more money is made available to the agency.

\section{CONCLUSION}

An appreciation of the activities of the UNHCR is necessary as the agency has greatly improved the conditions of refugees in many African countries. Many lives that should have been lost benefited from the benevolence of the agency. The UNHCR has not relented its effort in this direction; even at the time that most African countries find it difficult to accommodate refugees from neighbouring countries. The agency has expanded such protection through its partnership with many Non-governmental organisations. The efforts of these Nongovernmental organisations have gone a long way to compliment the UNHCR assistance to refugees.

\section{NOTES}

1 Such man-made and natural disasters include bush burning and over grazing of land for man-made, while earthquakes, flooding and desertification fall within natural disasters.

2 This fact has again been corroborated by Berman B.J. (1988): Ethnicity, Patronage and African State: The Politics of Uncivil Nationalism. African Affairs (1988) 97: 305-341.

3 Africa as at 2005 has a refugee population of over 7 million in addition to some 15 to 18 million internally displaced persons.

4 Worthy of note is that there had been pockets of refugee cases before the outbreak of World War I

5 The refugee population repatriated from both Tunisia and Morocco varied between 200,000 and 260,000

6 The UNHCR has been giving helping hand towards repatriation of refugees in Nigeria to different countries in Africa such as Liberia, Sierra Leone etc.

7 Majority of African countries are not abiding today by the decision they took at the O.A.U. (now AU) summit that they would allow refugees into their territories. 


\section{REFERENCES}

Adepoju, A 1982. "The Refugee situation in the Horn of Africa and Sudan." Africanist Opinion, xii (1 and 2): 29-34

Adepoju, A. 1982. "The Dimension of the Refugee Problem in Africa." African Affairs, 81(322): 2135.

Adisa, J. 1996. The Comfort of Strangers the Impact of Rwanda Refugees on Neighbouring Countries. Ibadan: IFRA.

Afolayan, A.A. 2003. "Dynamics of Refugee flows and Forced Repatriation in Africa." African Journal of Peace and Conflict Studies, 1(1): 66-90

Ajala, A. 1998. "The United Nations and African Refugees"' (Pp. 126-161) in: A.O. George and A Ajala (eds.), Africa and the United Nations: The First Fifty years: Lagos: Nigeria Institute of International Affairs.

Bakewell, O. 1999. "Returning refugees or migrating villagers? Voluntary repatriation programmes in Africa reconsidered." New Issues in Refugee Research, 15: 1-24.

Christensen, H. 1985. Refugees and Pioneers History and Field Study of a Burundian Settlement in Tanzania. Geneva.

Crisp, J. 1986. "Ugandan Refugees in Sudan and Zaire: The Problem of Repatriation." African Affairs, 85(338): 163-180.

Crisp, J. 1999. "A state of insecurity: the political economy of violence in refugees- populated areas of Kenya." New issues in Refugee Research, 16: 1-34.

Crisp, J. 2002. "No solutions in Sight: The Problem of protracted Refugee situations in Africa." New issues in Refugee Research, 68: 1-30.

Drumtra, J. 2003. "West Africa's Refugee Crisis Spills, Across many Borders" on-line (URL) http: // www.migration information. Org/feature/display Cfm? ID $=148$.

Gardam, J. and M. Jarvis. 2000. "Women and Armed conflict: The International Response to the Beijing Platform for Action in Columbia." Human Rights Law Review, 32(1): 1-65.

Gopalkrishna, S. 2005. The Refugee Problem in Africa. The Nigerian Daily Guardian Newspaper January 2, 2005 p 28.

Hamrell, S. (Ed.). 1967. Refugee Problem in Africa. Sweden: The Scandinavian Institute of African studies.

Ibeanu, O. 1998. "Exiles in their own Home: Internal population displacement in Nigeria." African Journal of Political Science, 3(2): 80-99.

Loescher, G. and L. Monahan. 1989. Refugees and International Relations. New York: Oxford University Press.

Nkrumah, K. 1973. Class Struggle in Africa. London: Panaf.
Nwosu, S and O. Djebah.1996. "Africa: Still the refugee continent." The Nigerian Daily Guardian Newspaper June 201996 p 13.

Odiaka, P. 2005. "Managing African refugee crisis as UN celebrates." The Nigerian Daily Guardian Newspaper July 52005 p 15.

Ogunkanmi, J. 1996. "UNHCR: Providing succour for refugees." The Nigerian Sunday Times Newspapers August 181996 p 7.

Oketunbi, T. 2000. "The wages of wars in Africa." The Nigerian Daily Guardian June 212000 p 19.

Petrin, S. 2002. "Refugee return and State reconstruction: a comparative analysis." New Issues in Refugee Research, 66: 1-23.

Prothero, R.M. 1987. "Populations on the move." Third World Quarterly, 9(4): 1282-1310.

Phillips, M. 2003. "The Role and impact of humanitarian assets in refugee-hosting countries." New Issues in Refugee Research, 84: 1-23.

Rutte, M. 2005. "The Reality of Return: IDPS in Darfur." Forced Migration Review, 24: 34-38.

Smyser, W.R. 1985. "Refugees: A Never Ending story." Foreign Affairs, 64(1-3): 154-168.

Van Hear, R. 2003. "From durable solutions to transitional relations: home and exile among Refugee diaspora." New issues in Refugee Research, 83:1-18.

Wilkin, D. 1980. "Refugees and British Administrative Policy in Northern Kenya, 1936-1938." African Affairs, LXXIX (317): 510-530.

Whittaker, B.E. 2002. "Changing priorities in refugee protection: The Rwandan repatriation from Tanzania". New issues in Refugee Research, 53: 1-16.

Zolberg, Suhrke Astri and Aguayo Sergio. 1989. Escape from Violence Conflict and the Refugee Crisis in the Developing World. New York: Oxford University Press.

Every man's United Nations 1968 A Complete Handbook of the Activities and Evolution of the United Nations During its First Twenty years, 1945-1965. New York: United Nations.

Refugee Policy Group Report. 1992. "Report on Internally Displaced: Women and Children in Africa." February Draft.

UNHCR. 1995. "UNHCR information bulletin on refugees of June." Geneva: UNCHCR.

UNHCR. 2000. "UNHCR official bulletin on refugees." UNHCR Report series, Vol. 4 No. 21, Geneva: UNHCR.

UNHCR: 2003. "UNHCR official bulletin on refugees." UNHCR Report, Vol. 2 No. 131, Geneva: UNHCR.

UNHCR. 2002. "Report of the United nations High Commissioner for Refugees." Geneva: UNHCR.

UNHCR. 2003. "Report of the United Nations High Commissioner for Refugees." Geneva: UNHCR.

USA. 2002. "Report on Sierra Leonean refugees" UNHCR. 2003. "Helping Refugees: An official bulletin on refugees." Geneva: UNHCR.

UNHCR. 2002. "UNHCR's programme for internally displaced persons in Sri-Lanka. Report of a joint appraisal mission by the UK." Geneva: UNHCR. 